\title{
Anti-Establishment Language Humour and Creativity in the Czech-Speaking Lands, 1938 to 1989
}

\section{TOM DICKINS}

ONE of the defining features of the Czech character, according to the national self-stereotype, is the propensity to laugh in the face of adversity. The Czechs' tendency to make light of things, even in difficult times, is encapsulated in the aphorism Sranda musí být, i kdyby na chleba nebylo ('You've got to have a laugh, even if you don't have a penny to your name'; more literally: 'There's got to be some fun, even if there's nothing left for bread'). Much of Czech humour has involved linguistic creativity, as evidenced, for example, in the literary works of Jaroslav Hašek (1883-1923), Karel Poláček (1892-1945) and Bohumil Hrabal (1914-97), or the comic double act of Voskovec (1905-81) and Werich (1929-80). It was, however, during the periods of the annexation of the Sudetenland and German occupation (1938-45) and Communism (1948-89) that language play and humour (interpreted broadly) performed their most overtly satirical and subversive functions. Under both regimes, word-based sedition was commonplace wherever it was felt to be sufficiently safe to lampoon the authorities, and was known and enjoyed by people with a range of perspectives (including some supporters and beneficiaries of the status quo). ${ }^{1}$

Several studies have addressed different aspects of anti-establishment humour, but the focus has generally been on the less culturally specific and

Tom Dickins is an Honorary Research Fellow of the University of Wolverhampton.

I am very grateful to Milan Paul for his comments on the first draft of this article.

1 This is confirmed, for instance, by Antonín Novotný (First Secretary of the Communist Party of Czechoslovakia, 1953-68; President of Czechoslovakia, 1957-68), in Rudolf Černý, Antonín Novotný: pozdní obhajoba, Prague, 1992, p. 30. 
less cerebral comedic expressions. ${ }^{2}$ There has been a tendency to downplay the linguistic and intertextual dimension of the humour (especially in publications aimed at non-Czech speakers). Typical is Petr Beckmann's collection of whispered jokes under Communism which, as he himself points out, excludes puns altogether, on the grounds that they are untranslatable. ${ }^{3}$ However understandable it might be to ignore the role of language play in its various guises (paranomasias, ambiguities, incongruities, double entendres, bons mots, innuendoes, interdiscursive allusions, and so on), the consequence of this approach is to disregard the essence of much of the humour. Even though it may not be possible to reproduce the wit of the original, 'meaning' can generally be rendered intelligible through a combination of deconstruction, explication and annotation. This study is not concerned with the merits of different approaches to translation which belong squarely in the field of translation studies - but rather with illuminating some of the less accessible aspects of language-based humour. This is not only essential for non-Czech speakers, but it may sometimes also be necessary for younger Czechs, who may be unfamiliar with earlier socio-cultural referents.

Political humour is often short-lived and context dependent, and draws on a wide range of linguistic devices, including rhyme, rhythm, parallelism, metathesis, metaphor, litotes and irony. In the Czech-speaking lands, from 1938 to 1989 , this mixture of the transitory and the rhetorical was especially characteristic of the language of street protest, as illustrated, for instance, in the rhyming couplets Ani vindru za zrádce Indru! (Not a penny farthing for the traitor Indra!), from 1968, or, Vrat se do strany, Milošku, bezpartijní tě nechtějí ani trošku (Go back to the [Communist] Party, Milošek; the non-Party members don't want you one bit), from 1989. ${ }^{4}$ Rhyme and semi-rhyme were especially prevalent in slogans,

2 Relevant publications include Christie Davies, 'Humour and Protest: Jokes under Communism', International Review of Social History, 52, 2007, S15, pp. 291-305; Antonin J. Obrdlik, "'Gallows Humor" - A Sociological Phenomenon', The American Journal of Sociology, 47, 1942, 5, pp. 709-16, and Blažena Gracová, 'Politická anekdota jako historický pramen', Moderní déjiny, 31 May 2010, pp. 1-9, available at <http://www.moderni-dejiny. cz/clanek/politicka-anekdota-jako-historicky-pramen/>.

3 Petr Beckmann, Whispered Anecdotes: Humor From Behind The Iron Curtain, Boulder, CO, 1969, p. 6.

4 Alois Indra was a hardline Communist politician and co-signatory (with Vasil Bilak, Antonín Kapek, Drahomír Kolder and Oldřich Švestka) of the so-called letter of invitation (zvací dopis) to Leonid Brezhnev, encouraging the Kremlin to take any action necessary to restore Marxism-Leninism. Miloš Jakeš was General Secretary of the Communist Party of Czechoslovakia from 17 December 1987 to 24 November 1989, and was subsequently expelled from the Party in December 1989. Note the use of the familiar, somewhat 
graffiti, ditties and verse, but they also featured in some other written and spoken media. 'Jokes' as such (as defined by the existence of a punch line or an extended metaphor) inevitably formed a major part of the antiestablishment repertoire under the Protectorate of Bohemia and Moravia and Communism. However, jokes by no means defined the genre, and they are of secondary importance here, except where their salient feature is their use of language play or metalinguistic narrative. ${ }^{6}$

The article seeks to plug the gap in existing knowledge (especially amongst foreign scholars) by focusing on selected political humour and creativity in the private sphere whose defining characteristic is its reliance on wordplay and/or interdiscursivity. The emphasis is on concise Czechlanguage expressions of anti-establishment sentiment which formed part of the vernacular canon, rather than on longer and more complex cultural manifestations of resistance. Examples of humour and inventiveness borrowed from or cited in languages other than Czech (as in the jokes identified by Ján L. Kalina in Slovak, ${ }^{8}$ or by Richard Marynčák in Polish, German and the Lachian dialect) are outside the scope of this work, although a few jokes which transcended the cultures of the Eastern bloc are included for the purpose of contextualization. Given the Czechs' predilection for wordplay, the illustrations chosen inevitably constitute only a small percentage of the overall total, but they nonetheless seek to represent a broad cross-section of the whole. The study touches both

disrespectful, diminutive 'Milošek' for 'Miloš'.

5 No attempt is made to reproduce rhyme in the translations in this article.

6 Amongst the joke books in Czech relating to the German occupation are Miloslav Baláš, Válečná ironie Čechư, Valašské Meziříćć, 1945; Edvard Cenek, Vlastimil Ziegner, Válečné anekdoty 1939-1945. Smích v bodláčí, Hořovice, 1945; Ladislav Khás, Nové pověsti české. 200 válečných vtipů, Prague, 1946; Oskar Krejčí, Zemé úsměvů 1939-1945, Prague, 1945; Richard Marynčák, Mějte nás rádi. Protifašistické anekdoty $z$ Těšinska i odjinud, Ostrava, 1965; Jaroslav Vojtěch, Hlas lidu. Světlé chvilky z temných dob 1938-1945, Prague, 1945. Joke books in Czech relating to Communism include Jiří Hradil, Jak jsme se smáli, abychom se nebáli aneb Lidová tradice z období stagnace, Prague 1991, and Ondřej Šebesta, Totalitní anekdoty, Prague, 2017.

7 In the interest of economizing on space, sources are not generally cited for wellknown examples of humour found in multiple publications and on different websites. However, special attention should be drawn to three publications (two academic and one popular), which list a particularly extensive and relevant range of examples: Bohuslav Beneš and Václav Hrníčko, Nápisy v ulicích, Brno, 1993; Jindřich Pecka, Spontánní projevy Pražského jara 1968-1969, Brno, 1993, and Jan Nejedlý, Jakub Šofar, Po práci legraci, vols 1-3, Brno, 2016-18.

8 Ján L. Kalina, Tisíc a jeden vtip: učebnica v-tipológie a žartizmu, Bratislava, 1969. Kalina's wittily subtitled list of jokes is worthy of note because of the accessibility and transferability of much of Slovak humour to Czech speakers, and vice versa, although Slovak wartime humour often had different targets to the Czech humour of the period. 
on why people manipulated language for humorous or satirical effect (the motivation) and on the humour's themes and intended targets (the message), but, unlike most other studies, its principal interest lies in the ways in which they did so (the medium).

In Hallidayan terms, the message equates broadly to the 'field' (conceived loosely here in terms of its distinguishing examples and leitmotivs); the motivation incorporates elements of the 'tenor' (relating to the interactional aspect of humour); the medium includes aspects of the 'mode' (the variety of language chosen and its channel of communication - written, spoken, chanted, sung). ${ }^{9}$ The medium may also refer to the style and rhetorical features of the utterances, which were typical of what Anna Wierzbicka has called political diglossia; that is, the co-existence within a totalitarian society of the official language with 'the unofficial, underground language of antipropaganda. ${ }^{10}$ Humour both drew on and directly contributed to this antipropagandistic tradition. Amongst its defining characteristics was the frequent use of slang and non-standard colloquial vocabulary, which represented a radical departure from the bombastic Soviet-inspired Communist language, termed 'la langue de bois' by Françoise Thom. ${ }^{11}$

Most anti-regime utterances were distinguished from officialese by their informality. As a rule of thumb, the greater the repression, the pithier the humour tended to be, not least because of the risks involved in saying too much. ${ }^{12}$ During the German occupation and the early Stalinist era, when a careless word to the wrong person could risk one's life, political humour mainly took the form of the Flüsterwitz (whispered joke), pun, catchy slogan or disparaging phrase repeated to trusted interlocutors in hushed tones. ${ }^{13}$ Despite the danger of committing such criticism to paper, a surprising number of written records survive from these times. ${ }^{14}$ One joke recounted how Emanuel Moravec (collaborationist Minister of Education,

9 M. A. K. Halliday and Ruqaiya Hasan, Language, Context, and Text: Aspects of Language in a Social-Semiotic Perspective, Oxford, 1985.

${ }_{10}$ Anna Wierzbicka, 'Antitotalitarian Language in Poland: Some Mechanisms of SelfDefense', Language in Society, 19, 1990, 1, pp. 1-59 (p. 1).

${ }^{11}$ Françoise Thom, Newspeak: The Language of Soviet Communism (La Langue de Bois), trans. Ken Connelly, London, 1989.

${ }^{12}$ For more on this, see 'The Origins of the Political Joke', in Chris Powell and George E. C. Paton (eds), Humour in Society: Resistance and Control, London, 1988, pp. 33-55 (p. 39).

${ }^{13}$ See, for instance, Hans-Jochen Gamm, Der Flüsterwitz im Dritten Reich, Munich, 1963.

${ }^{14}$ See, for example, Baláš, Válečná ironie Čechů; Krejčí, Země úsměvů, and Elliott Oring, Joking Asides: The Theory, Analysis, and Aesthetics of Humor, Boulder, CO, 2016, p. 123 . 
1942-45) went to the doctor with an abscess, only for the doctor to assert, 'Nothing can be done with it. You've just got to wait for it to go pop ( $a z z$ to praskne) and then we'll put you to the chop/guillotine (a pak vás budeme rezat)!'. In the relatively liberal mid-to-late 1960s, with the rise in opposition to Antonín Novotný, the humorous conceits became progressively more elaborate, and increasingly moved into the public sphere in song, drama, fiction and film (as in, say, Kundera's novel, The Joke or Miloš Forman's comedy movie, The Firemen's Ball). In the subsequent period of so-called normalization (1969-89), political humour became semi-muted again. Whilst in public, after 1968, people adhered to the Nazi-era adage Maul halten und weiter dienen (shut your gob and continue to serve), rendered in Czech by the zeugma držet hubu a krok (shut your gob and keep in step), in private, they indulged with even greater alacrity in seditious wordplay and joke-telling.

Jindrich Pecka subdivides the manifestations of dissent in 1968-89 into five broad categories (of which the middle three, in particular, were often characterized by humour): rumours (or zvěsti); slogans and graffiti; jokes (or anekdoty); verse and song; and prose genres and anonymous belles lettres (slovesnosti). ${ }^{15}$ The rumours related mainly to alleged cruelty and abuses of power, which did not find their way into the mainstream media, and were spread both orally and on paper. The subversive (written and shouted) slogans and (written) graffiti fell between the traditions of folklore and literature, and were largely inspired by the spoken word, as illustrated by Bohuslav Beneš and Václav Hrníčko. ${ }^{16}$ Some of the verbal and written forms of humour were accompanied by gestures, actions or visual props, and some of the slogans were pictorial or included a pictorial dimension (all of which are strictly beyond the remit of this article). Political jokes, and song and verse, were disseminated principally by word of mouth, although they sometimes also appeared in graffiti, private correspondence, samizdat publications and audio recordings. Prose genres and anonymous belles lettres, by dint of their greater complexity, were largely confined to print and hand-written documents and facsimiles.

15 Pecka, Spontánní projevy. All five categories existed to differing degrees both prior to and after this period, and represent a useful general typology of dissent under authoritarian rule.

${ }^{16}$ Beneš and Hrníčko, Nápisy v ulicích. The folkloric dimension of anti-establishment humour is similarly considered, in the context of the Protectorate, by Oldřich Sirovátka, 'Nad lidovou protektorátní anekdotou', Národopisné aktuality, 12, 1975, 3, pp. 189-98 (pp. 193-95). 


\section{The Motivation Behind the Humour}

The reasons for employing humour are disparate and complex, and vary according to the situation. Amongst the major academic theories of humour creation are the relief theory (which stresses its psychological role in reducing tension), the incongruity theory (which focuses on deviations from accepted or learned norms), and the superiority theory (which highlights the sense of triumph achieved by mocking the failings and misfortunes of others). ${ }^{17}$ These may take on different guises - each of which defines the humorist in relationship to his or her audience, the subject matter and the butt of the 'joke'. As John C. Meyer has noted, humour serves as both a unifier and a divider:

Humor use unites communicators though mutual identification and clarification of positions and values, while dividing them through differentiation of norms and differentiation of acceptable versus unacceptable behaviors or people. ${ }^{18}$

Anti-regime humour endorses the binary opposition between 'us' and 'them' established by the official propaganda, but reconfigures the paradigm so that the ruling elite represent the marginalized 'other', and their detractors constitute the disenfranchised majority. In other words, the many who are in on the 'joke' briefly become the arbiters of what is acceptable and just, while the powerful few and the norms that they promote are reduced to an object of ridicule.

Many of the interpretations of the functions of humour draw, at least to some extent, on the three major theories identified above. For example, Steve Linstead summarizes the roles of humour as follows: expressing playfulness ('humour as a "play" framework'); testing the atmosphere ('humour as exploration'); drawing dividing lines ('humour as performing a boundary-function'); reducing tension ('humour as a coping device'); and subverting the established organization of ideas ('humour as a characteristic quality of human structure'). ${ }^{19}$

Political humour is playful, in Linstead's sense, in that it represents a departure from the 'real' world, although its tone can vary hugely. It may be jovial or sombre, frivolous or heartfelt, light-hearted or earnest, upbeat

${ }^{17}$ See, for example, John C. Meyer, 'Humor as a Double-Edged Sword: Four Functions of Humor in Communication', Communication Theory, 10, 2000, 3, pp. 310-31.

${ }^{18}$ Ibid., p. 310.

19 Steve Linstead, 'Jokers Wild: The Importance of Humour in the Maintenance of Organizational Culture', Sociological Review, 33, 1985, 4, pp. 741-67. 
or negative, but it tends more towards the acerbic than the ludic, and it usually has a serious message. In Linstead's other terms of reference, the function of humour as a coping device takes precedence. Humour offers a form of light relief and escapism, which seeks to raise morale, especially in times of strife. Even the bleakest of gallows humour has a cathartic and restorative dimension - people laugh in extremis to mitigate pain and anxiety. The role of humour in creating a convivial atmosphere which lifts the spirits is, perhaps unsurprisingly, borne out by a series of psychological studies. ${ }^{20}$

As a form of exploration, humour places emphasis on extending the permissible and undermining recognized norms, at least within the private domain, in a Bakhtinian carnivalesque way. ${ }^{21} \mathrm{~A}$ well-timed joke or interjection may draw attention to a point which might otherwise be overlooked, and may change the tone and direction of a discourse. As a boundary-function, political humour redraws the conventional demarcation of different groups (traditionally based on ethnicity, geography, religion, gender, class and profession) along broadly ideological lines, although not all of those who see the 'funny' side of authoritarianism identify exclusively with the opposition. Finally, as a characteristic quality of human structure, humour questions the very nature of society, and accentuates the discordancy between official and unofficial 'realities'. It may thereby also help to disseminate information and normalize alternative perspectives, which act as a counterbalance to the approved authoritative discourse. As with other collective activities, the 'tenor' (or the community aspect of humour) may sometimes be even more significant than the 'field' (its message) and the 'mode' (the variety of language used). The shared nature of comedy is in itself palliative, irrespective of how funny the 'joke' may or may not be, and how well it is told.

In terms of Geoffrey Leech's (1974) model of language functions, the informational function of a humorous utterance (the knowledge that it imparts) is subordinate to the directive function (the way it influences others). The latter, in particular, is frequently informed by Leech's three other functions of language: the expressive function (its affective qualities), the aesthetic function (language as a linguistic artefact), and the phatic

${ }^{20}$ See, for example, Rod A. Martin, The Psychology of Humour: An Integrative Approach, Burlington, MA, San Diego, CA and London, 2007, p. 7.

${ }^{21}$ See, especially, Mikhail Bakhtin, 'Characteristics of Genre and Plot Composition in Dostoevsky's Works' (chapter 4), pp. 101-8o, in Problems of Dostoevsky's Poetics, trans. Caryl Emerson, Minneapolis, MN and London, 1984. 
function (its role in establishing lines of communication between people). ${ }^{22}$ Of particular relevance here are the directive and aesthetic functions of humour, but neither can be treated in isolation from the other functions. Anti-establishment humour performs a variety of interconnected roles, which together resonate with a significant cross-section of society.

Humour is not generally programmatic, although its principal themes, and the frequency of their occurrence, may sometimes serve as a checklist of the opposition's demands. A humorous utterance may likewise help to embolden the disaffected, and perhaps even to undermine the resolve of those whom it targets. Occasionally, when a critical mass of people rejects the imposed values, humour may contribute to a more coordinated form of dissent. This was especially evident in Czechoslovakia in the immediate aftermath of the Soviet-led occupation of 1968, when the distinction between the private and the public became blurred, and reform Communists actively endorsed the resistance. Yet, for all its passion, the bitter-sweet humour of late 1968 and early 1969 proved largely impotent, and possibly even counter-productive. As at other times of crisis and despair, the 'jokes' may have functioned partly as a displacement activity, which distracted from more direct and transformative courses of action. (That is not to suggest that all humorists were necessarily inclined to avoid more impactful forms of dissent.) Worthy of note here is that, based on the evidence of the sources employed for this study, humour was less prevalent during the Velvet Revolution of 1989, when the overthrow of the one-party system finally became an achievable goal, than it had been two decades earlier.

Needless to say, it is not possible to disaggregate or quantify people's motivations for engaging in anti-regime humour. We simply cannot know the full range of factors and developments that motivated individuals to lampoon the authorities. Neither can we know which of the theories of humour creation identified by Meyer and others (the relief theory, the incongruity theory, the superiority theory, and so forth) took precedence. However, we can assert, with some certainty, that insubordinate humour featured prominently in private discourse, and that a large part of its appeal resided in the form that it took (its linguistic medium). In other words, people frequently enjoyed the humour for its own sake, as an aesthetic experience, and not just because it implicitly or explicitly debunked the establishment.

${ }^{22}$ See Geoffrey Leech, Semantics: The Study of Meaning, Bungay, 1981, esp. pp. 40-42. 


\section{The Message of the Humour}

When considering the message (or, rather, the messages) of humour from 1938 to 1989, a clear distinction has to be drawn between the period of the Protectorate and the much longer and less uniform Communist era. In the former, the vast majority of Czechs were united throughout in their hostility to the Germans and National Socialism, and saw humour as one of the few tools in their armoury to express their opposition to German hegemony and military expansionism. The anti-establishment 'joke' served in defence both of Czech identity and the idea of the nation state. In the latter, there was strong initial enthusiasm for the Communist takeover and gratitude to the Soviet Union for its role in the liberation of Czechoslovakia in 1945 (which was successfully exploited by the authorities), accompanied by a widespread faith in the ideals of socialism. Although the realities of life under Communism altered many people's perceptions, the anti-regime humour did not, for the most part, challenge the existing geopolitical world order. Only occasionally, especially after the Soviet-led occupation of 1968, did jokes draw attention to the limitations of national self-determination; most famously, 'What is the most neutral country in the world (nejneutrálnèjši země na světě)?' - 'Czechoslovakia. She doesn't even intervene in her own internal affairs.'

The main defining characteristic of the anti-Nazi humour was its mockery of the German authorities and wartime events and conditions. In the early days, in particular, many of the language-based jokes highlighted the Czechs' sense of powerlessness, as in the account of a telephone call between Reinhard Heydrich (Reichsprotektor of Bohemia and Moravia, 1941-42) and Emil Hácha (President of Czechoslovakia, 1938-39; State President of the Protectorate of Bohemia and Moravia, 1939-45): Heydrich: 'Martial law [literally: "rights"] (stanné právo) is to be lifted.' - Hácha: 'Please don't do that. It is the only right (právo) that you have given the Czechs.' Other jokes sought to belittle the German people, as in 'Jaký je rozdíl mezi Římany a Němci?' - 'Římané věšeli lotry na kř́že a Němci věši krriže na lotry' ('What is the difference between the Romans and the Germans?' - 'The Romans hanged thieves on the cross and the Germans hang [iron] crosses on the thieves'). Several anti-German jokes punned on the phrase $v$ jiném stavu (in a different state = pregnant): 'Víte, že je Evropa $v$ jiném stavu?' - 'Jak to?' - 'No, bude mít malý Nèmecko.' ('Do you know that Europe is "in a different state"?' - 'What do you mean?' - 'Well, it will have a small Germany'), and 'But you know that Hitler's a decent fellow?' - 'How come?' - 'Well, you see, he got the republic “in[to] a 
different state", and then he got hitched (taky si ji potom vzal). ${ }^{23}$ Another joke relating to the subject of Hitler and marriage played on the idiomatic phrase dostat na frak (to have a thrashing; more literally: 'to have a dress suit sorted'): 'So, I hear Hitler's getting married.' - 'Get away with you.' - 'Yes, he's already had a thrashing / he's already got a dress suit sorted (už dostal na frak)'. As the situation deteriorated for the Nazis, the humour grew more confident, as in: 'Hitler has a rubber submarine (ponorka $s$ gumou), which will sail around Britain for as long as it takes for Britain to rub it out altogether (až ji úplně vygumuje)', and 'Hitler stands in front of a portrait of himself and asks, 'How's it all going to turn out?' The portrait replies, 'Put simply, they'll take me down and hang you [up] (mě sundajía tebe pověsí)'.

Even the darkest days of Stalinism were not perceived as negatively in the national consciousness as the German occupation, and most of the criticisms of state socialism fell short of direct comparisons between the two. Not only was the pro-Soviet regime not felt to threaten Czech (and Slovak) identity in the same way as National Socialism, but there was a widely held belief, at least up to the imposition of 'normalization' in 1969, that the shortcomings in society were an historical aberration, rather than a consequence of contradictions inherent in the system. It is noteworthy how many of the protesters' slogans in 1968 interpreted the Soviet-led intervention as a digression from Marxism-Leninism and not as a structural ideological problem. Typical were rhyming slogans such as Kdyby Lenin $z$ mrtvých vstal, prdel by vám nakopal! (If Lenin arose from the dead, he'd give your arse a kicking!) or Vymèním vázaného Lenina za svázaného Brežněva (I'll exchange a bandaged-up Lenin [in the Kremlin] for a tied-up Brezhnev). Perhaps the major distinguishing feature of the Communist-era wordplay and humour was its emphasis on the absurdities and injustices of the system. This is encapsulated in popular rhymes such as Jsi-li dobrý hospodářr, republice věrný, vytři prdel prstem, papír dej do sběrny (If you're a [decent] thrifty person, true to the republic, wipe your arse with your finger, and recycle the paper), and Uč se vole, budeš pánem, budeš jezdit tatraplánem (Study, you idiot, you'll be a nobleman, and you'll drive around in a Tatraplán), both from the $1950{ }^{24}$ The unjust nature of the regime is similarly reflected in slightly more sophisticated one-liners, such as 'In totalitarianism there is freedom of speech (svoboda projevu),

${ }^{23}$ The Czech phrase, 'taky si ji potom vzal', means both 'then he also took it/her the republic] over' and 'then he also took her [a pregnant woman] as his wife'.

${ }^{24}$ The Tatra 60o, popularly known as tatraplán, was a symbol of luxury, inaccessible to all except the Party bigwigs. 
but in democracy there is freedom after speech (svoboda po projevu)'. In a similar spirit was a well-known joke from the early 'normalization' period: 'Why do the Czechs no longer greet each other [with the Communist greeting] Práci čest (Honour to work)?' - 'Because those who have been vetted have lost their honour and those who haven't been vetted (have lost) their job (Protože ti prověrení ztratili čest a ti neprověrení práci)'. ${ }^{25}$ Two decades later, a joke at Husák's expense went: Husák: 'In 1968 we stood on the edge of an abyss (na okraji propasti). In the last twenty years, we have taken a giant step forward (velký krok vpred)'.

Yet, for all the differences between attitudes to the two authoritarian regimes, the expressions of humour also exhibit numerous commonalities, as evidenced both in joke books and academic studies. The most useful categorizations of anti-establishment humour in the context of the Protectorate and Czechoslovak Communism are probably those of Oldrich Sirovátka and Jiří Hradil, which both employ broad thematic classifications rather than a narrow chronological approach. ${ }^{26}$ There is no need to reproduce Sirovátka's and Hradil's typologies in full here. Suffice it to say, Sirovátka's schema identifies four major themes: 1) the system, ideology and institutions of Nazism, 2) a chronicle of military and political events, 3) everyday life in the Protectorate, 4) leading Nazis and their allies. Hradil groups his themes under three broad headings: From the Small Country (= Czechoslovakia), From Other Countries (= other socialist states), and From the Big Country (= the USSR). Sirovátka's first thematic grouping, which is of greatest relevance here, is sub-divided into ten discrete themes: 1) government jokes, 2) Party jokes, 3) Jewish jokes, 4) political jokes, 5) problems with supplies, 6) perestroika (ekonomická prestavba), 7) how we demonstrated, 8) other jokes from the town and village, 9) events in Chernobyl and 10) Love of the big brother. ${ }^{27}$ Within both Sirovátka's and Hradil's classifications, many of the examples relate either to the inadequacies, impositions, falsehoods, contradictions, callousness and stupidity of the imposed norms, or to the foibles, compromises and excesses of the regimes' adherents.

25 In 1968-69, the entire membership of the Communist Party and other people in professional or public positions were vetted over their view of the Warsaw Pact intervention. Those who expressed any disapproval of the occupation were penalized in various ways, and were generally demoted or dismissed from their jobs.

${ }^{26}$ Sirovátka, 'Nad lidovou protektorátní anekdotou', and Hradil, Jak jsme se smáli. Note that both studies focus almost exclusively on jokes, rather than other forms of language humour.

${ }^{27}$ Ibid., pp. 193-95 and pp. 6-48, respectively. 
The humour under both regimes varied from the abstract to the specific to the prosaic. Compare, for example, the following Communistera jokes: 1) 'Whereas under Capitalism man was exploited by man (byl vykořistován člověk člověkem), under Communism it was just the opposite'; 2) 'Three people argue about which country produces the cheapest tanks. The American says they can produce a tank for 2000 dollars; the German says they can produce one for 2000 marks; the Czech says 'we just need to say 2000 words, and the country is full of tanks (Nám stači ríct 2000 slov a máme tanků plnou republiku)'; ${ }^{28}$ 3) 'Under perestroika, several shops will have new names: Bílá labut' (White Swan) > Nebud' labut' (Don't Be Silly), Kotva (The Anchor) > Sotva (Hardly) and Máj (May) > Nemaj (They Don't Have)'.

\section{The Medium of the Humour}

The analysis which follows focuses on those examples of anti-establishment humour where the use of language was either of paramount importance in the creation of meaning or where it was a major contributor to the expression of meaning. In several of the examples cited, the message would appear to have been subordinate to the medium. That is to say, the effectiveness of the witty utterance (Leech's directive function) depended more on its form and the rhetorical devices that it employed (the aesthetic function) than on the ideas, values or information that it sought to impart (the informational function). Nonetheless, even where the linguistic dimension of the utterance was strongly foregrounded, the humour also implied a rejection of aspects of the status quo - be that the official hegemonic discourse, the behaviour of the ruling elite, or problems with day-to-day existence.

Language humour and creativity as a linguistic artefact took various forms from 1938 to 1989 , but the two (non-exclusive) ones that stand out were 1) metalinguistic playfulness (frequently characterized by punning or double entendres, and/or rhyme or semi-rhyme) and 2) intertextual and encoded referents.

\section{Metalinguistic playfulness}

While it may not always be possible to extricate altogether the message of anti-establishment humour from the medium, it is generally possible

28 'Two Thousand Words' was a reformist political manifesto written by Ludvík Vaculík in June 1968, which was roundly condemned by hardliners, and formed part of the justification of military intervention. 
to attribute a hierarchy to the medium and the message. In exceptional cases, the medium was the message. This is illustrated, for instance, in the repeated citation of General Blaskowitz's decree on behalf of Hitler: Na rozkas Votze a neivršiho Prezidenta německe Armady přrevzal sem $v$ zemi česke s nešnim dnem celou moc [in standard Czech: Na rozkaz vůdce a vrchního velitele nèmecké armády, převzal jsem ode dneška v zemi české plnou moc'] (On the order of the Führer and the Supreme Commander of the German army, I have as of today assumed full power.) Here, the series of lexical, morphological and orthographic errors serves to undermine the authority of the self-appointed German masters and to highlight their role as usurpers in the Czech-speaking lands. ${ }^{29}$

Elsewhere, the imposed medium of German became the discourse theme. In one well-known joke, Emil Hácha is informed of an inscription reading Hitler je vůl! (Hitler's an idiot!), and responds tetchily, 'No, prece to má být nejdř́v německy a potom teprve česky!' ('But I've said it should be in German first, and only afterwards in Czech!'). Here, the emphasis switches more directly to the absurdity of language policy, which prioritized the use of German over Czech in all official settings. Even though fluency in German was common amongst Czechs in the Protectorate, speaking Czech was a badge of honour for most people. As Albert Pražák has argued, the Czechs probably never discussed their mother tongue more than during the German occupation. ${ }^{30}$ Another joke from the same time went: Batovy závody prý budou uzavřeny. Odmítají vyrábět dvojjazyčné boty (It is said that Bata's [shoe] factories will be closed. They're refusing to produce double-tongued [bilingual] boots).

Of the many examples of Czech satirical humour which foregrounded the aesthetic function of language, the most frequently cited was possibly the text 'ČSSR očima zahraničního studenta' ('The Czechoslovak Socialist Republic Through the Eyes of a Foreign Student'). One of its several variants, which was widely duplicated, read: Těžkoslovensko je lihově demagogický stát se šokialistickým zřicením, šizený komickou stranou s výstředním úborem a polibdírou $v$ čele s geniálním nájemníkem rezidentem Mustafem Rusákem ([which might be loosely rendered as] Chunkyslovakia is a rotgut demagogic state with a shockialist wreckstablishment, cheated by the Comic Party with an eccentric camisole and a polyp burrow headed by the genius secret lessee, resident Mustafa Russ-axe). Most semieducated native speakers could immediately interpret this as a parody

29 The decree was also noteworthy because Fotze is a crude German word for 'vagina'.

30 Albert Pražák, Národ se bránil, Prague, 1946, p. 392. 
of Československo je lidově demokratický stát se socialistickým zrízením, řizený komunistickou stranou s ústředním výborem a politbyrem $v$ čele $s$ generálním tajemníkem Prezidentem Gustávem Husákem (Czechoslovakia is a people's democratic state with a socialist establishment, run by the Communist Party with a Central Committee and a politburo headed by the general secretary President Gustáv Husák). ${ }^{31}$

Many of the forms of wordplay where the medium took precedence over the message related to the subversion of names, titles and official descriptors. One example under the German occupation included the metathesis applied to the name Hermann Göring: Germán Hering, where 'Germán' is an old-fashioned pejorative term for 'a German' and 'Hering' (in German) means 'herring'. Another jibe at the German leadership employed the corrupted form Gaunerleiter from 'Gauleiter', for the leader of a regional branch of the National Socialist Party, where 'Gauner' means 'a scoundrel'. More famously, the noun protektorát (Protectorate) was substituted by protentokrát (for that time) and later protektokrad (for that theft). Pražák has argued that the phrase protentokrát was more than a joke; it was an expression of faith. ${ }^{32}$ In a similar linguistic vein, one popular anecdote described Roosevelt as a demokrat, Churchill as a plutokrat and Hitler as a 'všechnokrad' ('stole-all'). (The effectiveness of the semi-rhyme in the above two examples reflects the devoicing of the final /d/.) Amongst the many creative toponyms were Gib mehr (Give more) for Dejvice; Gestapodorf (Gestapo Village) and Es kommt der Tag (The Day is Come) for Hrdlořezy (literally: 'Cut-throats'); Heilige Regiment Böhmen Brücke (The Holy Regiment Bohemian Bridge) for Most Svatopluka Čecha (literally: 'The Svatopluk Čech Bridge'); ${ }^{33}$ Siegfriedslinie for Na Zbořeništi (literally: 'On the Site of a Ruin'); Lachau for Smíchov (smích/Lache = laugh[ter]); Dachau for Střešovice (střecha/Dach = roof).

Much of the anti-regime language humour involved playing around with abbreviations and letters. One example from the Nazi era ran: Konec války bude, ažSA a SS budou volat SOS do USA, že SSSR je v ČS (The end of

${ }^{31}$ Amongst the phrases which defy easy translation in the caricature are lihove (literally: 'alcoholic') for lidově (people’s); šizený (literally: 'duped') for řízený (run); výstrední úbor (literally: 'way-out attire') for ústřední výbor (Central Committee); the neologism polibdíra (literally: 'lick-arse') for politbyro (politburo); geniální nájemník (literally: 'the genius tenant') for generálni tajemník (general secretary); and the name Mustaf[a] Rusák for Gustáv Husák (which combines a variant of the common Arabic first name with a pejorative term for a Russian).

${ }^{32}$ Pražák, Národ se bránil, p. 391.

33 This plays on the fact that svatý means 'holy', pluk means 'regiment' and Čech means 'Bohemian'. 
the war will be when the SA [Brown Shirts] and SS send an SOS to the USA to say that the USSR is in the ČS [Czech lands]). Many of the abbreviations sought to poke fun at the imposed language norms. For example, the new initialism for Czech railways, $B M B-C M D$ (Böhmisch-Mährische Bahn - Českomoravské dráhy [The Bohemian-Moravian Railway]) was popularly reinterpreted as Budete mít Beneše - čalouníka máme dost (You'll get Beneš - we've had enough of the little upholsterer [Hitler]). ${ }^{34}$ The omnipresent capitalized initial $V$, denoting 'victory' (Victoria), was also frequently reinterpreted as Ven ([Get] Out), Vitězství (Victory [for the Czechs]) and Verloren ('lost' in German), as well as by more complex constructions, such as Vưdce Vyrábí Voloviny (The Führer is Talking Rot) and Vy Volové Věríte Ve Vitězství Vưdce (You Idiots Believe in the Victory of the Führer). ${ }^{35}$ The Germans' much-vaunted aspiration of increasing output in the factories was likewise symbolically sabotaged by the Czechs' reinterpretation of the phrase produktivita práce (productivity of labour) as pracuj pomalu (work slowly), which was shortened to $P P$. Other forms of linguistic creativity included redefining the meaning of common words as acronyms, as in ahoj (hi/bye) > Adolfa Hitlera oběsíme jistě (we'll hang Adolf Hitler certainly) and vrah (murderer) > Vüdce rajchu Adolf Hitler (Führer of the Reich, Adolf Hitler).

The metalinguistic humour which was characteristic of life under German rule persisted thereafter. Anti-Communist sentiment was evident in several of the more playful unofficial opposition election slogans of 1946; for example, Kdo volí ćíslo jedna je blbý jak bedna [kytu] (Anyone who votes for number one [that is, the number drawn by the Communist Party] is as daft as a box [of putty] = as daft as a brush); Volte prdel, volte stehna, jen nevolte číslo jedna! (Vote for an arse, vote for thighs, just don't vote number one!); Ten kdo není extremista, fašista či totalista, voli dvojku dozajista (If you're not an extremist, a fascist or a totalitarian, you vote number two [the Czechoslovak People's Party], to be sure). ${ }^{36}$ After the Communist takeover

${ }^{34}$ Edvard Beneš was President of Czechoslovakia from 1935 to 1938 and 1945 to 1948, and was in charge of the Czechoslovak government-in-exile from 1939 to 1945. Hitler was sometimes referred to as 'the little upholsterer', perhaps by association with his good friend, the musician August Kubizek, who spent long hours in his father's upholstery firm.

${ }^{35}$ See, for example, Alena A. Fidlerová, Robert Dittmann, František Martínek, Kateřina Voleková, Dějiny češtiny, 2013, p. 144, available at <https://docplayer.cz/32265193-Dejinycestiny-alena-a-fidlerova-robert-dittmann-frantisek-martinek-katerina-volekova.html>, and Ivan Hanousek, 'Nanynka a lidová protistátní tvořivost', MF Dnes, no date, available at <http://www.svet.czsk.net/clanky/publicistika/protestyhumor.html>.

${ }^{36}$ See František Čapka and Jitka Lunerová, 1948: Vitězný únor, Brno, 2012, p. 74. Note that the post-war period was dominated by the Communist Party, which enjoyed far 
in 1948, there was a belief amongst some opponents of the regime that the system would not last, as reflected in rhetorical questions such as $K d y$ to praskne? and Kdy to rupne? (When will it all go pop? = go up in smoke); do švestek (till plum-picking time; i.e. the autumn); až se to (v)obrátí (until it changes).

The Communists' penchant for initialisms and acronyms, which was at least partly attributable to Russian influence, ${ }^{37}$ proved to be an especially rich source of parodic inspiration. Redefinitions included KSČ (Komunistická strana Československa) (Communist Party of Czechoslovakia) > Konec Srandy, Čecháčkové (The end of the laugh, [you] narrow-minded Czechs); MUKL (Muž určený k likvidaci) (Man destined for liquidation = labour camp prisoner [in the 1950s]) $>$ Muž určený $k$ lopatě (Man destined for the shovel); $M U D r$ (Medicinae universae doctor) (Doctor of Medicine) > Musiš umřit, dělej rychle (You've got to die; do so quickly); Pomocná stráž VB (The Auxiliary Guard of Public Security [i.e. the regular police]) > Pitomec stojící vedle blbce (An idiot standing alongside a fool); RVHP (Rada vzájemné hospodářské pomoci) (The Council for Mutual Economic Assistance) > Ráno vyjedeš, hovno přivezeš (You will go out in the morning and bring back bugger-all); SČSP (Svaz československosovětského prátelství) (The Union of Czechoslovak-Soviet Friendship) $>$ Svaz Čechù strachem posraných (The Union of Czechs covered in shit through fear); SNB (Sbor národní bezpečnosti) (National Security Corps [i.e. the national police force]) $>$ Seru na brigádu (I don't give a damn about vacation work). After the occupation of 1968, when initial mass emigration was followed by stringent travel restrictions, the initialism CKM (Cestovní kancelár mládeže) (Young Persons' Travel Office) was reinterpreted by some as Cestujeme, kam můžeme (We travel where we can). In the 1970 s and 1980s, district and regional secretariats (okresní a krajské výbory) were sometimes referred to by the acronym kokos (short for komunistický kostel [Communist church]). In 1989, a slogan read simply, but effectively, KSČ, vratte nám Kčs (KSČ, return our Kčs [Czechoslovak crowns]).

The organizing principles of Communism were frequently treated as an object of ridicule, as in the slogans Raději blbé zrrízení, než nutnost myšlení (We'd rather have a stupid system than be made to think), from the 1965 student May festival parade (majáles); and, from 1989, Srdcem strany je obušek. Dokud bije, strana žije! (The truncheon is the beating heart of the Party. While it still beats, the Party is alive!); Dusitko od firmy KSČ dusí

greater support than any of the other parties.

37 See, for example, Miloš Helcl, 'Zkratková slova', Naše řeč, 33, 1949, 9-10, pp. 161-70. 
nejlépe! (The [musical] mute by the firm KSČ muffles [sound] best!); Naše heslo - pustte veslo! (Our slogan - let go of the oar!); 40 let jsme byli vedeni stranou, ted'chceme jít rovně (For 40 years we've been led astray/ by the party, but now we want to go straight). ${ }^{38}$ Disrespectful expressions for ordinary Party members also abounded; for example, komundíra (díra = hole), komanč, komár (mosquito), komín (chimney) and komouš. Communist sympathizers were similarly dismissed in scornful terms, such as načichlý (tainted), zapojený (attached), společensky angažovaný (socially engaged), rudý jezdec (red rider), na druhé straně barikády (on the other side of the barricade), $u$ nich (with them).

The Communist leadership featured in much of the linguistic creativity. Nicknames applied to the Party hierarchy included rudý děda (red uncle) and rudý satan (red satan) for Zdeňek Nejedlý (Minister of Education and Culture, 1948-53); Tonda Harmonika/Antonín Harmonikár (Tonda the Harmonica Player), Zápotonda/Tonda Zápota (perhaps suggestive of zapotit [to sweat]), Antonín Dobrotivý (Antonín the Gracious), and ušaté torpedo (the eared torpedo), for Antonín Zápotocký (President of Czechoslovakia, 1953-57); ${ }^{39}$ and schöne Toni and Antonín sličný (Antonín the Comely) for President Novotný, which alluded to his good looks, but implied his vanity. Other leading Party members who were targeted included František Kahuda (Minister of Education, 1954-63), in the 1956 majáles; Alois Indra in 1968; and Vasil Mohorita (President of the Central Committee of the Socialist Union of Youth and a Communist negotiator), in 1989: Co Komenský vytvoŕil, to Kahuda potlačil! (What Comenius created, Kahuda suppressed!); Chceme Dubčeka, žádné Indrikány! (We want Dubček, no 'Indrikány' [intrikány = schemers]); Mohorita-totalitaod koryta (Mohorita-Totalitarianism-on the gravy train; literally: 'out of the trough'). ${ }^{40}$ Perhaps the most reviled of Czechoslovak politicians was Vasil Bilak (Secretary of the Central Committee of the Communist Party of Czechoslovakia, November 1968 to December 1989). One joke, aimed at Bilak, told of an official visit to France, where the Communist apparatchiks decide to increase their prestige by giving themselves the prefix 'de'. President Husák said he would be known as 'de Hus'; Prime

\footnotetext{
${ }^{38}$ The word stranou is both the instrumental form of strana and an adverb meaning 'astray'.

39 Zápotocký, who was regarded as a man of the people by some Czechs, was an accomplished harmonica player, and had large auricles.

40 Jan Amos Komenský (Comenius) (1592-1670) was a philosopher, educator and theologian. Alexander Dubček was First Secretary of the Communist Party of Czechoslovakia from 5 January 1968 to 17 April 1969.
} 
Minister Štrougal opted for 'de Štroug'; Bilak immediately declared that he would not be going. ${ }^{41}$ A further object of derision was Marta Gottwaldová (wife of Klement Gottwald, the first Workers' President, 1948-53), who was referred to as Martička prdelatá (big-bottomed Martička) because of her corpulence, and was ridiculed for allegedly answering to the noble title milostpaní (Her Ladyship). ${ }^{42}$

Gustáv Husák (First Secretary of the Communist Party, 1969-87; President of Czechoslovakia, 1975-89) came in for particular censure because of his collusion with the Kremlin in 1968. Amongst the epithets applied to him were Gusta (whence gustapo for his police force); Gustáv samozvanec (Gustáv the Usurper) - an allusion to the description of members of Charter 77 as Ztroskotanci a samozvanci (Down-and-outs and usurpers); ${ }^{43}$ Hnusák (hnus = disgust); Rusák (Russki); and opeřenec (the feathered friend), which played on the meaning of his surname 'gander'. In 1969, the Brno theatre Divadlo husa na provázku (The Theatre of the Goose on a String) was required to drop the word husa because a wag had changed posters to Divadlo Husáka na provázku (The Theatre of Husák on a String). Other subversive references to Husák included the phrase Socialismus s husí kůží (Socialism with goose bumps) for 'normalization' - an allusion to 'socialism with a human face', and the renaming of the Žižkov transmitter to Husákưv prst (Husák's finger) and of Těšnov tunnel (by the entrance to the Central Committee building) to Husákovo ticho (Husák's silence), since it was claimed that it had been built to spare him from traffic noise. Jokes also took Husák's name in vain; for example, 'Co je to degustace?' ('What is “degustation"?') - 'Zhodnoceni prezidenta Gustáva Husáka' ('An evaluation of President Husák'), and 'What is the difference between Husák's time and Hus's time?' - 'I don't know.' - 'Purely grammatical. In Hus's time they burnt people on a bonfire (upalovali lidi na hranici), and in Husák's time they burnt people going over the border (upalovali lidi za hranici)' - both common in 1989. ${ }^{44}$

A number of the slogans played on polysemous words, where the secondary meaning of the word (with an initial capital letter) is also a proper noun. Notable examples were beran (ram), čepička (forage cap), svoboda (freedom), císař (emperor) and komárek (mosquito) - Rudolf Beran was Prime Minister of Czechoslovakia (from December 1938 to March 1939) and Prime Minister of the Protectorate of Bohemia and

\footnotetext{
${ }^{41}$ The noun debil in Czech means 'simpleton'.

${ }^{42}$ Note the deliberate inappropriate use of the diminutive 'Martička'.

${ }^{43}$ Unnamed eds, 'Ztroskotanci a samozvanci', Rudé právo, 12 January 1977.

${ }^{44}$ Jan Hus (c.1370-1415) was a Czech theologian and philosopher.
} 
Moravia (from March to April, 1939); Alexej Čepička was Minister of Defence (1950-56); Ludvík Svoboda was President of Czechoslovakia (1968-75); Čestmír Císař was Chairman of the Czech National Council (1968-69); Valtr Komárek was an economist and politician active in the Velvet Revolution and thereafter. Puns on their names included Budeme se muset od nynějška naučit jak bečet, protože náš vi̊dce je Beran (We'll have to learn how to bleat from now on because our leader is a ram/Beran), from 1938; ${ }^{45}$ Ještě jeden Čepička a budem sloužit od malička (One more forage cap/Čepička, and we'll be in the services from an early age), from the 1956 majáles; At žije s/Svoboda! (Long live freedom/Svoboda!), from 1968; Chtěli jsme c/Císaře a máme cara (We wanted an emperor/Císař and we have a tsar), also from 1968; Chceme více takovýchto k/Komárků (We want more such mosquitoes/Komáreks), from 1989. Of a similar ilk were references during the Protectorate to two types of cockroach, rus and šváb, which (when capitalized) also mean 'Russian' and 'Swabian', respectively. A wartime joke ran, 'What is Europe?' - 'Europe is a place where rusi hunt švábi (Evropa je místo, kde rusi honí šváby)'. This theme was amended in a series of slogans in 1968, including DDT je proti švábům, celý svět je proti rusưm (DDT is [used] against švábi, the whole world is against rusi); Kupujte DDT. Lezou k nám švábi a rusi. (Buy DDT. Švábi and rusi are crawling towards us); Praha zaplavena odporným hmyzem — šváby a rusy (Prague is flooded with disgusting insects - švábi and rusi).

Examples of wordplay at the expense of leading Communists were not confined to the Czechoslovak political hierarchy. One popular joke ran, 'Jak se nèmecky řekne "správnè”?' - 'Richtig' - “Nesprávně”?' - 'Unrichtig' "A úplně blbě"?' - 'Ulbrichtig'. ('How do you say in German "correctly"?' — 'Richtig' - “'Incorrectly"?' - 'Unrichtig' - 'And "completely stupid”?' — 'Ulbrichtig'). ${ }^{46}$ Another joke (which more or less works in English) puns on a modal verb: 'a foreigner goes up to a Czech and says, 'Poslyšte, ta Stalinova socha, všude ty Leninovy obrazy - vy ten Sovětský svaz ale musite mit rádi.' ('Look here, Stalin's statue, pictures of Lenin everywhere - you must just love the Soviet Union'); to which the Czech replies, 'Jo. Musime.' ('Yep. We must.'). More prosaically, the shop sign Ovoce-zelenina (Fruit and Vegetables) was sometimes referred to as Ovoce $z$ Lenina (Fruit out of Lenin).

45 The noun beran also means 'a wrong-headed person'.

${ }^{46}$ Walter Ulbricht was First Secretary of the Socialist Unity Party of Germany (the East German Communist Party) from 1950 to 1971. 
Several jokes, puns and slogans drew attention to the shortages in the shops. One from the period of the Protectorate simultaneously sought to raise morale: 'There will be lots of beef without ration cards at Christmas.' - 'How come?' - 'They'll slaughter the bull/idiots [budou porážet ty voly] who still believe that Hitler will win. ${ }^{47}$ The Czechs' preoccupation with the lack of basic provisions continued into the Communist era. As Christie Davies has pointed out, 'The greatest number of Eastern European jokes directly concerned with the irrationality of the system deal with the failures of central economic planning, particularly in relation to agriculture and consumer goods. ${ }^{48}$ These failures are reflected, for instance, in the popular name given to the monstrous statue of Stalin in Prague - Fronta na maso (The meat queue), as well as a series of jokes. A well-known joke from the 196os punned on a remark attributed to President Novotný: 'Maso bude vbrzku' (We'll have meat soon) - 'Kdežto Brzko je' (Wherever Brzko is). ${ }^{49}$ Another joke with a similar theme went as follows: 'The sign above the butcher's shop used to read Butcher (̌̌eznik), and inside the shop there was meat. Now, the sign above the shop reads Meat (Maso), and inside the shop there's ... a butcher'. Similar jokes, less dependent on language (and thus found with variations in other Communist bloc countries), included: 'They say that there's meat in Prague; will we have it in Brno, too?' - 'Yes, the exhibition is mobile'; 'What would happen if there were Communism in the Sahara desert?' - 'Within a year there'd be queues for sand'; 'What are the four biggest problems of socialism?' - 'Spring, summer, autumn and winter.'

A whole series of creative maxims highlighted people's negative attitude to work and to state property under Communism. Examples included Oni předstírají, že nás platí, my předstíráme, že pracujeme (They pretend to pay us; we pretend to work), also found in the languages of other Communist countries; Kdo nekrade, okrádá rodinu (If you don't steal [from the state], you steal from your family); Co ukradneš ve fabrice, to zůstane v republice (What you steal from the factory will stay in the republic); Kdo pưl smény neprofláká, ten pracuje pro Husáka (If you don't idle away half your shift, you're working for Husák); Vadí-li pivo při práci, prestaň pracovat (If you're concerned about beer at work, stop working); Co můžeš udělat dnes nedělej ani zitra a máš dva dny volna (What you can’t do today, don’t do tomorrow

47 The slogan plays on the polysemy of the word vưl (bull/idiot).

${ }^{48}$ Christie Davies, 'Stupidity and Rationality', pp. 1-32 (p. 25), in Powell and Paton (eds), Humour in Society.

49 'Brzko' sounds like a Czech place name. The adverb 'vbrzku' (soon) is suggestive of 'v Brzku' (in Brzko). 
either, and you'll have two days off); Kdo nic nedělá, nic nezkazí (If you do nothing, you damage nothing).

A particular feature of Czech linguistic creativity was the listing of various aphoristic 'commandments' to fellow citizens. One such example, popularized by Werich went: 1. Nemysli. 2. Když myslís, tak nemluv. 3. Když mysliš a mluvíš, tak nepiš. 4. Když myslís, mluvíš a píšeš, tak se nepodepisuj. 5. Když mysliš, mluvišs, píšeš a podepisuješ se, tak se nediv (1. Don’t think. 2. When you think, don't speak. 3. When you think and speak, don't write. 4. When you think, speak and write, don't sign your name. 5. When you think, speak and write, and sign your name, then don't be surprised). Others, in 1968, gave advice, for example, on how to behave and how speak to Soviet soldiers: '1. Don't know, 2. Don't care, 3. Don't tell', and so on. The overt function of these directives was to counsel caution, but their covert function was to undermine the regime. Similarly, the grammatical case system was sometimes employed to make a political point, as in the example from 1989: Umís česky? První pád: Jakeš / druhy pád: bez Štěpána / trètí pád: $k$ Demokracii / čtvrtý pád; co? Pravdu! / pátý pád: voláme - Svobodné volby! / Šestý pád: o více stranách / sedmý pád: společně s lidem. (Do you know Czech? First case [nominative]: Jakeš / second case [genitive]: without Štěpán / third case [dative]: towards Democracy / fourth case [accusative]: what? The Truth! / fifth case [vocative]: we call - Free elections! / sixth case [locative]: about more parties / seventh case [instrumental]: together with the people). ${ }^{50}$

Whilst most aspects of Soviet-imposed rule were fair game to opponents of the regime, things Russian were not generally subject to the same degree of serious criticism, at least until 1968. The Warsaw Pact intervention, however, led to a re-evaluation of Czechs' attitude to their erstwhile ally. Numerous slogans and ditties illustrated this new perspective; for instance, Běžte domů, Ivani, čekají vás Číñani! (Go home, Ivans, the Chinese are waiting for you); Dnes ruská vejce zdarma! (Russian eggs [a popular dish] free today!); Lepší Dubčekova svoboda, nežli ruská dohoda! (We'd rather have Dubček's freedom than the Russian agreement [the Moscow Protocol, which spelt an end to reform Communism]); Ruskej buran chce náš uran (The Russian yokel wants our uranium); Už jsou tu Rusové, už jsou tu zas, za pytel p̌senice drancujou nás (The Russians are here now, the Russians are here again; for a sack of wheat, they plunder us). One joke went: 'Are Russians brothers or friends?' - 'Brothers of course; people can choose

50 Miroslav Štěpán was the Secretary of the Municipal Party Committee in Prague (1988-89) and a member of the Central Committee of the Communist Party (1988-89). 
their friends (přátele si člověk může vybrat!)'. Several slogans similarly employed Russian lexical exoticisms to make their point. Examples (with the Russian loanwords highlighted in bold) included Bravo, rebjata Hitler (Well done, lads - Hitler); Nenič naši dlažbu tanky, vrat' se radši do zemljanky! (Don't destroy our road surfaces with your tanks; go back, instead, to your dug-outs!); Sedte doma na dvorku a kuřte svou machorku! (Sit at home in your backyard and smoke your cheap tobacco); Rusové, jděte do stepi, krávy potřebují voly! (Russians, go to the steppes, the cows need bulls/idiots!).

Elsewhere, anti-Soviet sentiment often took the form of jibes at the supposed superiority of everything Soviet, as in the slogan Sovètskýzáchod — náš vzor (the Soviet toilet - our model) - a play on Sovětský svaz náš vzor (the Soviet Union - our model). Soviet watches were described as the quickest in the world (nejrychlejší na světě) and Soviet dwarves as the biggest in the world (největší na světě). Language boffins even coined a further degree of comparison for 'good': dobrý (good), lepši (better), nejlepši (best), sovětský (Soviet).

\section{Intertextual and encoded referents}

Much of the humour and wordplay (in which the medium matched or exceeded in importance the message) alluded to cultural realities. One wartime joke ran: 'It's raining bombs on Hamburg. Praguers ask each other what a destroyed Hamburg will be called? The reply to the uninitiated is Městečko na dlani (Our little town in full view). ${ }^{51}$ Another joke went: 'Goebbels attends a performance of Bedrrich Smetana's comic opera The Bartered Bride at the National Theatre. After the performance he announces that he really enjoyed it, except that, in his view, the role of (the marriage broker) Kecal ("Windbag") was slightly diminished. Apparently, they have a much better one in the Reich (Mají prýv Řiši mnohem lepšího)'.

A slogan from 1968 read: BESTSELLER! Leonid Iljič Brežněv: Bylo nás pět na jednoho (BESTSELLER! Leonid Il'ich Brezhnev: There were five of us against one) - a reference both to Poláček's humorous novel Bylo nás pèt (There were Five of Us), published in 1946, and to the military intervention by five of the Warsaw Pact countries (the Soviet Union, Bulgaria, East Germany, Hungary and Poland). A rhyming slogan from this time played on the same referent: Dřív jsme mèli prátel pět, ted' jich máme plnej svět (We used to have five friends; now we have a whole [non-

51 The tragi-comic film Městečko na dlani (1942) depicts the fate of the citizens of an idyllic small town at the end of the nineteenth century. 
Communist] world full of them). Another slogan read Červený šátečku, kolem se toč, príijeli Rusové, já nevím proč (Little red headscarf, give [us] a twirl, the Russians have come, and I don't know why), which alluded to the children's song Červený šátečku, kolem se toč, but was inspired by an anti Austro-Hungarian First World War parody of the same song, Červený šátečku, kolem se toč, my jdeme na Rusa, nevíme proč! ([...] we have a go at the Russians and we don't know why!). ${ }^{52}$

Two of the principal state 'symbols', the Czechoslovak coat of arms and the national anthem, featured as intertextual referents in the Communist era, as in the slogans Hlas českého lva: Vratte mi mou korunu, ta hvězda byla na zálohu (The voice of the Bohemian lion: Return my crown to me, the star was a deposit), and, from 1968, Zde domov můj a kde tvůj, Váňo, Koljo, Alexeji? (This is my home, and where's yours, [you Russians] Vanya, Kolya, Aleksei?). ${ }^{53}$ Other cultural referents included Juraj Jánošík (the Carpathian Robin Hood), Emil Zátopek (the long-distance runner, who opposed the 1968 occupation) and Julius Fučík (the Communist journalist and writer). Examples included Zapojme se v jeden šik, Dubček je náš Jánošík (Let's form into single file, Dubček is our Jánošík); Čtyřicitka - žádnývěk, chytte si mě! Zátopek (Forty is no age, catch me [if you can]! — Zátopek); Fučíku, promiň, že jsme nebděli (Forgive us, Fučík, for not being watchful!). ${ }^{54}$ More bizarrely, in July 1989, Miloš Jakeš was mocked for a phrase that he himself had used in a speech to local party activists in the town of Červený Hrádek: jak kůl v ploté (to be completely alone in the world; literally: 'like a stake in the fence'). ${ }^{55}$ Jakešs warning of the danger of Communists being isolated 'like a fencepost' entered into Czechoslovak folklore, and was exploited in a series of slogans, including Nechceme kůl v plotě!! (We don't want a stake in the fence); Nechceme nový plot ze starých kůlů (We don't want a new fence from old stakes); Havel není kůl v plotě ([Václav] Havel is not a stake in the fence).$^{56}$ In 1989 , Bilak was similarly derided for extracts from his autobiography, Milníky mého života (Milestones of My Life), as in the slogan Historici všech zemi, spojte se při studiu knihy Vasila Bilaka Milníky

52 The Czechoslovak legions in the Soviet Union frequently found themselves in conflict with the Bolsheviks.

${ }^{53}$ In 1961, the red star replaced the crown above the Bohemian lion on the coat of arms. Zde domov mi̊j alluded to the national anthem Kde domoj můj (Where is my home).

${ }^{54}$ Julius Fuč́k's last known words, from Plötzensee Prison in Berlin in 1943, before he was hanged, were Lidé, bděte! (People, be watchful!).

${ }^{55}$ For a recording of the speech, see $<$ https://www.youtube.com/watch?v=cKoQQo8gd $\mathrm{PM}>$.

56 The writer and opposition leader Václav Havel was President of Czechoslovakia from 1989 to 1992 and first President of the Czech Republic from 1993 to 2003. 
môjho života. Nebo omylniky? (Historians of the world unite in the study of Vasila Bilak's book Milníky môjho života. Or 'mi[stake]lestones'?). ${ }^{57}$

Proverbs, sayings and aphorisms provided especially rich material for satire under Communism. For example, the proverb Všude dobře, ale doma nejlip (It's good everywhere, but home is best [There is no place like home]) was sometimes modified to Všude dobře, tak co tady? (It's good everywhere, so what are we doing here?). In 1968, the occupying forces were greeted by the salutation Chleba pro vás nemáme a sưl neprodáváme (We don't have bread for you and we won't sell [you] salt), in contravention of stereotypical Slavonic hospitality. A number of the slogans similarly played on the popular self-stereotype Co Čech, to muzikant (If you're Czech, you're a musician), as in Co Čech, to muzikant, co Rus, to okupant ([...], if you're Russian, you're an occupier); [...], to demonstrant ([...], you're a protester); Co Čech, to muzikant. Jak dlouho budeme hrát druhé housle? ([...]. How long will we play the second fiddle?).

One of the most productive sources of seditious metalinguistic inspiration was the turgid official propaganda. For instance, one wellknown joke mocked the Communists' obsession with the collective noun lid (the people): 'Jaký je rozdíl mezi lidem a lidmi za socialismu?' - 'Lid buduje novou a spravedlivou společnost a statečně překonává všechny překážky, kdežto lidi na to kašlou' ('What is the difference between the people and people under socialism?' - 'The people build a new and fair society and courageously overcome all the obstacles, whereas people couldn't give a damn about it!'). ${ }^{58}$ A similar playfulness characterized the subversion of the ubiquitous Communist Party slogans. Examples relating to the early Communist period included Ano zrno, nazdar! (Not a grain, hello!) for Ani zrno nazmar! (Not a grain to be wasted!); Čelem $k$ masu! (Facing the meat!) for Čelem k masám! (Facing the masses!); Poroučejte si větru, dešti - ale ne nám! (You direct the wind and rain — but not us!) for Poručime větru, dešti! (We will direct the wind and the rain!); Komunistưm více práce at' nechají agitace (More work for the Communists, so that they give up their propagandizing) for Republice více práce - to je naše agitace (More work for the Republic - that is our rallying-cry); Komunisté! Politicky po staru se žít nedá (Communists! We cannot live politically in

57 The portmanteau neologism omylníky combines omyly (mistakes) with milníky (milestones). Passages from Milníky mého života (originally in Slovak: Milníky môjho života) started to appear, without Bilak's authorization, in the samizdat newspaper, Lidové noviny, in 1988. His full autobiography was subsequently published under the title Paméti Vasila Bilaka, 2 vols, Prague, 1991.

${ }_{58}$ The use of the colloquial form lidi accentuates the difference. 
the old way) for Po staru se žit nedá..$^{9}$ Other comic slogans included $A t$ žije komunistická sranda Československa! (Long live the Communist laugh of Czechoslovakia!) for At’žije Komunistická strana Československa! (Long live the Communist Party of Czechoslovakia!); Bud’v práci v šest! (Be at work at six!) for Bud' práci čest! (Glory be to work!); V národu je síla, $v$ prdeli je díra! (There is strength in the people, there is a hole in the arse! [an inscription found on toilet walls]) for $V$ jednoté je sila (There is strength in unity); Dobří lidé/Studenti všech zemí, spojte se! (Good people/Students of the world, unite!) for Proletári všech zemí, spojte se! (Workers of the world unite!). In 1989, during the Velvet Revolution, a slogan developed the latter theme as follows: Malér, soudruzi - proletáři všech zemí se konečně spojili (Trouble, comrades - the workers of the world have finally united).

Numerous counter slogans, especially in 1968, played on the official slogan Se Sovětským svazem na věčné časy (With the Soviet Union for evermore); for example, Se Sovětským svazem na věčné časy, ale ani o vteřinu déle! ([...], but not for a second longer!); Se Sovětským svazem na věčné časy a jindy nijak! ([...], but at other times, no way!); Se Sovětským svazem do věčné basy ([...] into the eternal nick); Němci nás chtěli na tisíc let, Rusové na věčné časy (The Germans [under Nazism] wanted us for a thousand years, the Russians for evermore). A banner unfurled by exiles at the 1983 Ice Hockey World Championships in Munich, which was seen by millions of Czechoslovak citizens on state television, read Bijte Rusy na věčné časy a nikdy jinak! (Beat the Russians for evermore and never anything different!).

Sometimes the humour was more encoded, and relied on the addressee to decrypt it. This was especially evident in the 1956 and 1965 majálesy, where incongruous visual and textual elements combined. Dominik Želinský and Werner Binder have applied Umberto Eco's (1998) descriptor 'semiological guerrilla warfare' to this allegorical technique (in the context both of the Prague and the Bratislava majálesy). ${ }^{60}$ Suffice it to mention here one example, from the Prague 1956 majáles, where meaning was dependent on the interaction of the visual and the textual. A group of students carried a model of a dinosaur, with two messages inscribed on either side of it one read Pro studentskou mensu (For the student canteen), which could be interpreted to mean that the meat offered to the students was old and of poor quality; the other read Jsem nezranitelný. Mám kưži tak hrubou,

59 Po staru se žít nedá was the title of a book by Antonín Zápotocký, published in 1948.

${ }^{60}$ Dominik Želinský, Werner Binder, 'How Not to Prepare Majales: A MeaningCentred Analysis of Subversive Student Performances in Communist Czechoslovakia', Sociální studia / Social Studies, 4, 2016, pp. 61-79 (p. 72). 
jako minist. školství (I am invulnerable. I have skin as tough as that of the Minist. of Education!), which suggested that no amount of criticism would have any impact or result in change. ${ }^{61}$

Elsewhere, the sheer absurdity of the students' proclamations served to subvert the official discourse. Some of their slogans undermined the Communist narrative stylistically and conceptually whilst seemingly endorsing it, as in At žije menzovní žrádlo! (Long live [the lousy] student canteen grub!), and Funkcionář jsou včele, vždycky když se někam jede! (Functionaries are in the vanguard whenever there's a good thing to be had!), from 1956; and, from 1965, Sovětský majáles náš vzor! (The Soviet majáles - our model!), and Nejezte sandwich, jezte ruská vejce, vejce našich prátel (Don't eat a sandwich; eat Russian eggs - the eggs of our friends). ${ }^{62}$ Other slogans highlighted the inherent contradictions in the Communists' idealized world, including Ginsberg králem majálesu výraz proletárského internacionalismu (Ginsberg, King of the majáles - an expression of proletarian internationalism). Far from celebrating proletarian internationalism, the deliberately provocative appointment of the American poet and writer Allen Ginsberg as king of the parade in 1965 drew attention to the limitations of the official interpretation of international working-class solidarity. In several slogans the collision between the reality of Communism and everyday experience was made more explicit still, as in Ročně nové učebnice, at jsme blbí ještě více (New textbooks every year, so we can be even dafter), from 1956, and Chceme 10 let vojny, armáda dá reakci na záda - hurá! (We want ten years of military service, the army will kick the opposition's backside — hurrah!), from 1965.

\section{Conclusion}

This article has sought to address a phenomenon that has been largely overlooked in academic studies - the medium of language-based antiestablishment humour and creativity in the Czech-speaking lands from 1938 to 1989. The paucity of scholarship on this theme (especially in languages other than Czech and Slovak) is perhaps unsurprising, given that much of the wit and subtlety of the utterances is inevitably lost in translation. The aim here has not been to attempt to reproduce the humour or the compositional qualities of the original (although where

${ }^{61}$ John P. C. Matthews, 'Majales: The Abortive Student Revolt in Czechoslovakia in 1956', Cold War International History Project, Working Paper No. 24, Washington, D.C., 1998, pp. 5-37 (pp. 28-29) has pointed out that the abbreviation minist. could apply either to the Minister of Education, František Kahuda, or to the Ministry itself.

${ }^{62}$ The term vejce colloquially also means 'balls'. 
this has been achieved, it is a bonus), but rather to illustrate and synthesize the linguistic inventiveness of a range of entertaining critical responses to the authoritarian discourse. It has been shown that wordplay and intertextuality performed such a key function in Czech humour that to ignore them is to neglect a major part of the nation's cultural narrative. The manipulation of language was one of the few means by which people could express their disapproval of the status quo whilst simultaneously indulging in both private and collective fun. As Chad Bryant has stressed, humour may not have been an especially heroic act of defiance, but it drew people together. $^{63}$

The role of humour in exposing falsehoods and unpalatable realities is universally acknowledged, as in the Latin phrase 'Ridentem dicere verum quid vetat?' (What prevents me from speaking the truth with a smile?), whence perhaps 'Many a true word spoken in jest', and Czech 'Žertem nejsnáze pravda se poví' (It's easiest to tell the truth through a joke) or 'Žertem pravdu prohoditi neškodí' (It doesn't hurt to let the truth slip out in a joke). ${ }^{64}$ The Czechs have always been adept at letting the truth slip out in amusing and original ways, often in response to a sense of impotence and disenfranchisement. They have also been acutely aware of the importance of the function of language in asserting their own identity, not least because the Czechoslovak state (in which the Czechspeaking majority played the leading role) was founded on ethnolinguistic nationalism.

Seditious humour and wordplay under both National Socialism and Communism had the goal of highlighting deficiencies in the imposed norms (lies, injustices, abuses of power, absurdities, hypocrisy, and so forth), hence the critique of the two polities inevitably exhibited numerous similarities. Under both regimes, language-based humour also represented an act of self-empowerment; yet, the ideological motivation for this selfempowerment differed significantly in the two cases. In the former, the humour sought to undermine German hegemony and, by implication at least, to defend the very idea of Czech nationhood. Under Communism, the humour was targeted more directly at political distortions, especially at those aspects of the system that were seen as inimical to fairness, justice and freedom of speech. Whether the humour had any practical effect on policy making or people's everyday behaviour remains a matter of

${ }^{63}$ Chad Bryant, 'The Language of Resistance? Czech Jokes and Joke-Telling under Nazi Occupation, 1943-45', Journal of Contemporary History, 41, 2006, 1, pp. 133-51 (esp. p. 140).

${ }^{6}$ See Jarmila Bachmannová, Valentin Suksov, Jak se to řekne jinde. Česká př́ísloví a jejich jinojazyčné protějšky, Prague, 2007, p. 216 
conjecture. There may be anecdotal evidence to suggest that some creative oppositional calls for action were heeded, as in the wartime exhortation pracuj pomalu (work slowly), abbreviated to $P P$, and in entreaties, in 1968, for people not to collaborate, such as Ignorujte okupanty! K jídlu jim nic nedejte, radši všechno sežerte! (Ignore the occupiers! Don’t give them anything to eat, but rather scoff it all yourself!). However, even in such cases it is not possible to ascertain precisely the role of the linguistic medium in influencing the public's response. The perlocutionary force (or broader impact) of the witty utterances is inherently unknowable and unquantifiable.

What is beyond doubt is that symbolically the irreverence and ridicule subverted the established order. People found pleasure and solace in antiregime humour both as a form of escapism and as an aesthetic experience. The language of antipropaganda, of which humour was a major part, offered a much-needed counterbalance to the oppressive official discourse. Wierzbicka is categoric about the positive psychological effects of the antipropaganda:

[...] an underground language constitutes a form of national self-defense against the brainwashing effects of propaganda. It promotes underground attitudes; it helps to reduce the fear and to strengthen the spirit of defiance and the wish to resist. Its role in the preservation of national identity, spirit, and inner freedom cannot be overestimated. ${ }^{65}$

The response of both the Nazis and the Communists lends support to Wierzbicka's assertions. While the German authorities may have been sanguine about the Czechs' relative acquiescence during the occupation, there is no questioning the frustration evinced in Heydrich's oft-cited depiction of the Czechs as 'lachende Schweine' (laughing swine). The problems for the Germans were compounded by their imperfect knowledge of Czech and their lack of frame of cultural reference, as well as by the pride (even Schadenfreude) that the Czechs took in speaking their own language. The Communist authorities were similarly unamused by jibes at their expense, to judge by documentary evidence, such as the secret police reports on the Prague majáles, in 1956, held in the National Archive. ${ }^{66}$

Undesirable as the humour might have been to those in power, it may have paradoxically sometimes also worked in their favour. By reducing

65 Wierzbicka, 'Antitotalitarian language in Poland', p. 8.

${ }^{66}$ See Národní archiv, Fond 014/12 Svazek 23 Ar. j.: 820, pp. 1-15 (p. 2). 
tension (in accordance with the relief theory), the jocular taunts may have served as a safety valve, which inhibited more radical forms of resistance (especially in times of stability). The fact that so many people told jokes and indulged in wordplay, with relatively few being arrested for the activity, suggests that humour was not generally regarded as a major threat to the system. The longevity of the Communist regime further testifies to the shortfalls of wit as a tool for transformation. It is telling that in 1989, when meaningful reform was finally achievable, appeals for action by the opposition movement Civic Forum were not, for the most part, characterized by humour and linguistic creativity. Typical were sober but perspicuous slogans, such as Délníci, nepotřebujeme jen vaše ruce, ale i vaše srdce (Workers, we need not only your hands, but also your hearts). Amongst the more thought-provoking and insightful slogans from 1989 was one which focused specifically on the limitations of laughter as an expression of discontent: 21 let humoru není žádná legrace! (21 years of humour is no joke!). Had the originator of the slogan taken a longer historical perspective, the message might have read 'Half a century of humour is no joke (but it has provided a very welcome distraction!)'. 